\title{
Water Footprint Assessment of Thai Banana Production
}

\author{
Cheerawit Rattanapan and Weerawat Ounsaneha
}

\begin{abstract}
The aim of this research was to assess the water footprint level of Thai banana production. Firstly, the water consumption inventory of banana production was developed. The water consumptions in the banana farms and a case study of banana industry were collected based on the inventory. The results showed that the water consumption of banana plantation was $842.02 \mathrm{~m}^{3}$ including $443.50 \mathrm{~m}^{3}$ of green water, $398.52 \mathrm{~m}^{3}$ of blue water and not found grey water. Moreover, $1638.59 \mathrm{~m}^{3} /$ rai was found in the one rai of banana plantation consisted of $863.06 \mathrm{~m}^{3} / \mathrm{rai}$ of green water and $775.53 \mathrm{~m}^{3} / \mathrm{rai}$ of blue water. From the finding of this study, the reduction approach of water footprint for banana production should be the reduction of watering the plant in the process of banana growing.
\end{abstract}

Index Terms - Water footprint, water consumption, banana production, life cycle assessment, Thailand.

\section{INTRODUCTION}

The banana, belonging to the family Musaceae, is a highly common plant in tropical and subtropical countries [1]. Banana is a potential carbohydrate source for food consumption and could be used to formulate several kinds of desserts and functional foods [2]. About 144 million tons/year of banana is widely produced in the worldwide and over 234,000 tons were produced for demand of Thai and international consumption in 2013 [3], [4]. Besides, Office of Agricultural Economics, Thailand [5] presented that the dominant area of banana plantation with the low chemical use Thailand was found in the central part of Thailand.

The water requirements to grow food, supply industry and sustainable urban and rural populations has led to an increasing shortage of fresh water in many parts of the world [6]-[8]. To date, the increasing pollutant contamination at their water resources and the development of suitable management plan were presented in various countries. The number of global standards is quite limited in order of providing better comparison of different regions of the world [9]. Mekonnen and Hoekstra [10] recommended that the water footprint is the principle measurement for assessing the level of human appropriation of water resources. The total volumes of fresh water consumption and contamination were presented by producers and consumers from both direct and indirect ways throughout supply chain [9]-[11]. This measurement will be performed as a volumetric amount of water, without considering water use impacts on the region, and therefore this paper showed a water footprint inventory

Manuscript received August 25, 2020; revised March 23, 2021.

Cheerawit Rattanapan is with ASEAN Institute for Health Development, Mahidol University, Thailand (e-mail: cheerawit.rat@mahidol.ac.th).

Weerawat Ounsaneha is with Faculty of Science and Technology, Valaya Alongkorn Rajabhat University under the Royal Patronage, Thailand (corresponding author; e-mail: weerawat@vru.ac.th). analysis [12].

From the study of Clercx et al. [13] mentioned that the average water footprints of banana production in the small banana farmers in Peru and Ecuador were $576 \mathrm{~m}^{3} / \mathrm{t}$ in Ecuador and $599 \mathrm{~m}^{3} / \mathrm{t}$, respectively. These finding presented that the sustainability of the water footprint is questionable in both countries for increasing the water productivity and better quality of banana fruits. Rattanapan and Ounsaneha [4] indentify that the water consumption is the important parameter of life cycle inventory for Thai banana supply chain.

Hence, the aim of this study was assess the water footprint of banana production in Thailand. Firstly, the water consumption inventory was generated and then the volumes of water consumption in banana plantation and industry were collected by life cycle assessment. Finally, the water footprint reduction approach was recommended for proposing the sustainable water consumption in Thai banana production.

\section{MAterial AND MethodS}

\section{A. Goal and Scope Definition}

1) The water footprint assessment of Thai banana plantation consisted of soil preparation, banana plantation, fertilizer use, pest control and harvesting. The input resources of banana plantation were water, fertilizer and fuel consumption and the output of this process was only the waste generation (Fig. 1).

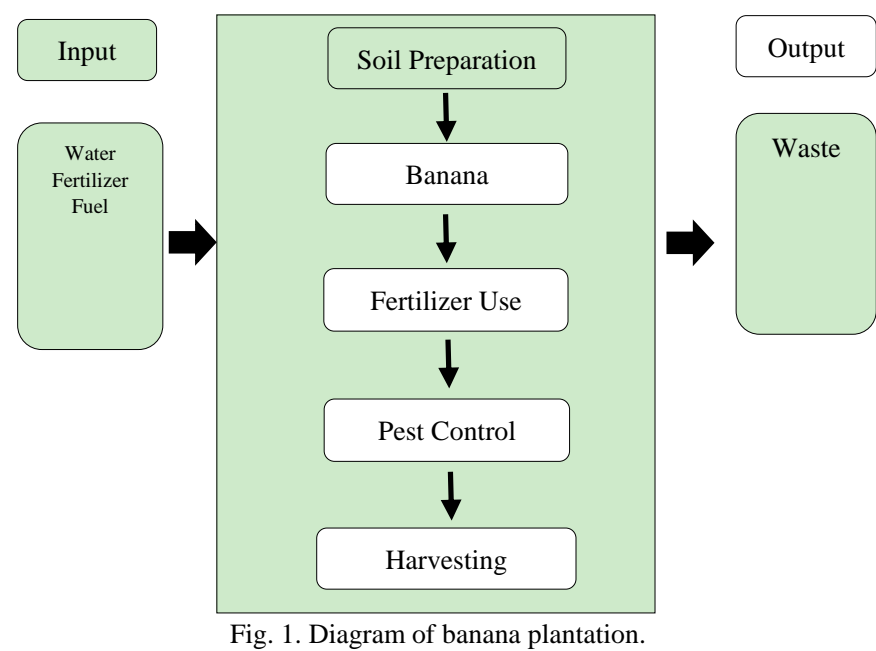

2) The water footprint assessment of Thai banana production consisted of transportation, cutting, cleaning and drying, conveyor belt, screening, packing, and reprinting processes. The input resources of banana production were water, fuel and electricity consumption 
and the output of this process was only the waste generation (Fig. 2).

3) The consumption data from a one company and banana farms in the central parts was collected in this study.

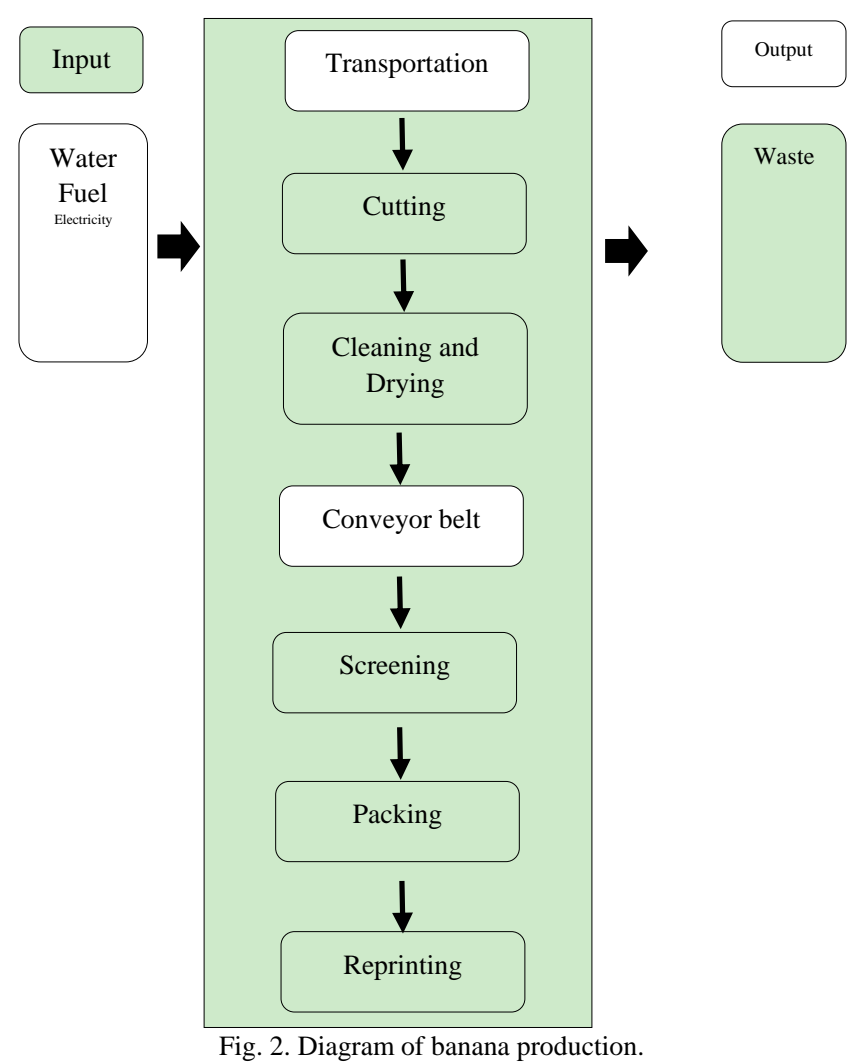

\section{B. Water Footprint Inventory}

The primary data from banana farms and factor in the central part of Thailand was collection in the period of 2018 by the face-to-face interview and observation. The life cycle resources of banana supply chain including banana plantation, water, fertilizer, fuel, and electricity consumption were conducted. Moreover, secondary data of waster footprint assessment was includes from the related study or report with the scientific references.

\section{Water Footprint Assessment}

The water consumption inventory was developed from the primary survey and then was used to assess the water footprint performance in the agriculture and industry section. Firstly, the data of soil, climate, plan and map were collected from the literature review and related study and then were used to calculate the crop water use and Crop Evapotranspiration by CROPWAT 8.0 software. The Crop Evapotranspiration; ET was calculated by the green and blue of water footprint values in equation 1 . The crop water use was calculated by gray of water based on equation 2 [14].

$$
\begin{gathered}
\text { WFgreen }=\frac{\text { CWUgreen }}{\mathrm{Y}} \\
\text { WFblue }=\frac{\text { CWUblue }}{\mathrm{Y}} \\
\text { WFgrey }=\frac{\alpha) \times \mathrm{AR}) /(\text { Cmax }- \text { Cnat })}{\mathrm{Y}}
\end{gathered}
$$

Note:

$C W U=$ Crop water use $\left(\mathrm{m}^{3} /\right.$ rai $)$

$Y=$ Crop Yield $(\mathrm{kg} / \mathrm{rai})$

Cmax and Cnat $=$ the maximum concentration and concentration in the nature mass (mass/volume)

The total water footprint was calculated by following equation 4 :

$$
\text { WFproc }=\text { WFgreen }+ \text { WFgreen }+ \text { WFgrey }
$$

\section{RESUlT AND DisCUSSION}

\section{A. Life Cycle Inventory of Thai Banana Production}

The life cycle inventories of Thai banana production consisted of banana plantation and production was shown in Table I and II, respectively. The input of life cycle inventory for the banana plantation collected from two banana farm consisted of root, chemical fertilizer, organic fertilizer, pesticide, herbicide, fuel, electricity, rain water and water use. The main input of banana plantation was the chemical fertilizers as 52.37 kilogram/rai. This finding was consistency with the report of Rattanapan and Ounsaneha [4] because the nitrogen and potassium was the main requirement for banana plantation. Moreover, the water use and rain water for plantation process were 833.70 and 714.24 $\mathrm{m}^{3} /$ Rai, respectively. Table II showed the life cycle inventory of banana production, the main life cycle of banana production consisted of banana, water use, electricity, bag, tape, sticker and acetylene gas. The electricity use was the main input of this process because the electricity is used mainly for lighting and for operating pumps that extract

\begin{tabular}{|c|c|c|c|}
\hline Order & Inventory & Quantity & Unit \\
\hline \multicolumn{4}{|l|}{ Input } \\
\hline 1. & Root & 300 & Root/Rai \\
\hline 2. & $\begin{array}{l}\text { Chemical Fertilizer } \\
0-0-60 \\
46-0-0 \\
15-15-15 \\
21-0-0\end{array}$ & $\begin{array}{c}52.37 \\
2.5 \\
6.5 \\
34.5 \\
8.87\end{array}$ & $\begin{array}{l}\mathrm{kg} / \mathrm{Rai} \\
\mathrm{kg} / \mathrm{Rai} \\
\mathrm{kg} / \mathrm{Rai} \\
\mathrm{kg} / \mathrm{Rai} \\
\mathrm{kg} / \text { Rai }\end{array}$ \\
\hline 3. & Organic Fertilizer & 25 & $\mathrm{~kg} / \mathrm{Rai}$ \\
\hline 4. & Pesticides & 7 & $\mathrm{~kg} / \mathrm{Rai}$ \\
\hline 5. & Herbicide & 0.40 & L/Rai \\
\hline \multirow[t]{3}{*}{6.} & Fuel & & \\
\hline & Diesel & 78.46 & L/Rai \\
\hline & Benzene & 164.25 & L/Rai \\
\hline 7. & Electricity & 6.79 & Kwh/ Rai \\
\hline 8. & Rain water & 833.70 & $\mathrm{~m}^{3} / \mathrm{Rai}$ \\
\hline 9. & Water use & 714.24 & $\mathrm{~m}^{3} / \mathrm{Rai}$ \\
\hline \multicolumn{4}{|l|}{ Output } \\
\hline 1. & Banana & 1.9 & Ton/ Rai \\
\hline
\end{tabular}
water from wells and bananas is also transported within the facility on conveyor belts powered by electricity [15].

TABLE I: LIFE CYCLE INVENTORY OF THAI BANANA PLANTATION

\section{B. The Parameter Information for Banana Production by CROPWAT 8.0}

The objective of this research was to assess the water footprint of banana production with the calculation of water volume in the real banana plantation. From the comparison with the water consumption of banana (Etc) with the rain 
consumption (Peff), The ETc value can be calculated by the plant coefficient from the report of Allen multiply with the reference of the water consumption from the CROPWAT 8.0 software. The meteorological data during 2013 - 2018 from Phra Nakhon Si Ayutthaya meteorological station was used to compute in this study. The detail of the rain consumption by USDA was following:

1) Climate and water consumption of banana (climate/ET0)

The water consumption of banana (ET0) was assessed by CROPWAT 8.0 with Penman-Monteith equation. The result found (Table III) that the maximum and minimum of water consumptions were $4.85 \mathrm{~mL} /$ day in May and $3.51 \mathrm{~mL} /$ day in December, respectively. This value was lower than the reference standard $(3.51 \mathrm{~mL} /$ day $)$ because of the humidity and high temperature in the plantation area in this study.

TABLE II: LIFE CYCLE INVENTORY OF THAI BANANA PRODUCTION

\begin{tabular}{clcc}
\hline \hline Order & Inventory & Quantity & Unit \\
\hline Input & & & Ton \\
1. & Banana & 2625 & $\mathrm{~m} 3 /$ Prodcut \\
2. & Water use & 0.04 & $\mathrm{kWh} . /$ Prodcut \\
3. & Electricity & 0.042 & $\mathrm{~kg} / \mathrm{Rai}$ \\
4. & Bag & 0.00007 & $\mathrm{~kg} / \mathrm{Rai}$ \\
5. & Tape & 0.000006 & $\mathrm{~kg} / \mathrm{Rai}$ \\
6. & Sticker & 0.000001 & $\mathrm{~kg} / \mathrm{Rai}$ \\
7. & Acetylene gas & 0.00078 & \\
Output & & & $\mathrm{kg} / \mathrm{Rai}$ \\
1. & Banana Product & 2348 & \\
2. & Waste & 1.23 & \\
\hline \hline
\end{tabular}

TABLE III: CLIMATE AND WATER CONSUMPTION OF REFERNCE PLANT

\begin{tabular}{lcccccc}
\hline \hline Months & $\begin{array}{c}\text { Minimum } \\
\text { Temperature } \\
\left({ }^{\mathbf{C}} \mathbf{C}\right)\end{array}$ & $\begin{array}{c}\text { Maximum } \\
\text { Temperature } \\
\left({ }^{\circ} \mathbf{C}\right)\end{array}$ & $\begin{array}{c}\text { Humanity } \\
(\text { Percentage) }\end{array}$ & $\begin{array}{c}\text { Wind } \\
\text { Speed } \\
(\mathbf{M} / \mathbf{S})\end{array}$ & $\begin{array}{c}\text { The } \\
\text { length of } \\
\text { sunlight } \\
(\mathbf{H})\end{array}$ & $\begin{array}{c}\text { Water } \\
\text { consumption } \\
\text { of reference } \\
\text { plan }\end{array}$ \\
\hline Jan & 20.1 & 32.7 & 70 & 66 & 7.4 & 3.53 \\
Feb & 21.9 & 34.4 & 69.3 & 65 & 7.4 & 4.00 \\
Mar & 24.2 & 36.2 & 72.3 & 63 & 7.4 & 4.56 \\
Apr & 24.9 & 37.1 & 71.8 & 64 & 7.2 & 4.82 \\
May & 25.2 & 37.2 & 72.4 & 64 & 7.1 & 4.85 \\
Jun & 24.6 & 35.5 & 76 & 64 & 4.9 & 4.05 \\
Jul & 24.3 & 34.4 & 78 & 63 & 3.7 & 3.62 \\
Aug & 23.9 & 34.0 & 80.3 & 56 & 3.4 & 3.45 \\
Sep & 23.7 & 33.5 & 83.3 & 49 & 4.6 & 3.60 \\
Oct & 23.2 & 33.6 & 81.6 & 53 & 5.9 & 3.68 \\
Nov & 22.4 & 33.6 & 76.5 & 72 & 7.2 & 3.75 \\
Dec & 20.4 & 32.1 & 69.1 & 82 & 7.1 & 3.51 \\
AVG & $\mathbf{2 3 . 2}$ & $\mathbf{3 4 . 5}$ & $\mathbf{7 5}$ & $\mathbf{6 3}$ & $\mathbf{6 . 1}$ & $\mathbf{3 . 9 5}$ \\
& & & & & & \\
\hline
\end{tabular}

Source: CROPWAT 8.0

2) Rainfall $\left(\mathrm{P}_{\text {eff }}\right)$ and Rainy

The rainfall consumption ( $\mathrm{E}_{\mathrm{ff}}$.rain), $\mathrm{P}_{\mathrm{eff}}$ was conducted by USDA method with the assumption on over and lower of 250 $\mathrm{Mm}$ of rainy value. The result showed that the rainfall and rainy consumptions were $1048.00 \mathrm{~mm}$ and $833.70 \mathrm{~mm}$ (Table IV).

3) Plan parameter of banana plantation

The period of banana plantation consisted of 4 periods including Period 1: offshoot to plan pot, Period 2: early growth (found leaves), Period 3: initial growth (found blossom) and Period 4: final growth (from blossom to production). The detail of plan parameter in each period of banana plantation was shown in Table V.
TABLE IV: RAINFALL AND RAINY CONSUMPTION

\begin{tabular}{|c|c|}
\hline Months & Rainy (mm/months) \\
\hline Jan & 7.80 \\
\hline Feb & 12.90 \\
\hline Mar & 58.90 \\
\hline Apr & 51.90 \\
\hline May & 92.10 \\
\hline Jun & 124.60 \\
\hline Jul & 134.00 \\
\hline Aug & 170.00 \\
\hline Sep & 190.00 \\
\hline Oct & 127.90 \\
\hline Nov & 62.90 \\
\hline Dec & 14.90 \\
\hline AVG & 1048.00 \\
\hline
\end{tabular}

Source: CROPWAT 8.0

TABLE V: PLANT PARAMETER OF BANANA PLANTATION

\begin{tabular}{lcccc}
\hline \hline \multicolumn{1}{c}{ Plan parameter of } & \multicolumn{4}{c}{ each period } \\
\cline { 2 - 5 } banana plantation & period 1 & period 2 & period 3 & period 4 \\
\hline Days & 90 & 165 & 45 & 30 \\
Plan coefficient & 0.50 & 0 & 1.10 & 1.00 \\
Root depth & 0.30 & 0 & 0.90 & 0.90 \\
Dehydration crisis & 0.55 & 0 & 0.45 & 0.45 \\
Adjusting value & 1.00 & 1.00 & 1.00 & 1.00 \\
Height & 0 & 0 & 3.00 & 0 \\
\hline \hline Source: CROPWAT 8.0 & \multicolumn{5}{c}{}
\end{tabular}

\section{4) Soil parameter}

The soil parameters in this study were the total of humanity, the highest rate of penetration of water through soil, the highest of depth root, the initial decrease of soil moisture and the initial of total humanity. The details of soil parameter were shown in Table VI.

TABLE VI: SOIL PARAMETER OF BANANA PLANTATION

\begin{tabular}{ccc}
\hline \hline Soil parameters & Values & Unit \\
\hline Total of humanity & 200 & $\mathrm{Mm} / \mathrm{m}$ \\
Highest rate of penetration of & 30 & $\mathrm{Mm} / \mathrm{day}$ \\
$\quad$ water & 900 & centimeter \\
$\begin{array}{c}\text { Highest of depth root } \\
\text { Initial decrease of soil } \\
\text { moisture }\end{array}$ & 50 & Percentage \\
the initial of total humanity & 100 & $\mathrm{Mm} / \mathrm{m}$ \\
\hline \hline
\end{tabular}

\section{Water Footprint of Thai Banana plantation}

The water footprint of Thai banana plantation was assessed by the data collection from banana farm of Ayutthaya province, Thailand. The details of water footprint assessment are following:

1) Crop Coefficient $(\mathrm{Kc})$

In this research, Crop Coefficient of banana plantation was investigated by Crop Coefficient in each period of banana growth. The Crop Coefficient of each period was shown in Table VII.

TABLE VII: CROP COEFFICIENT OF WATER CONSUMPTION IN EACH GROWTH PERIOD FOR BANANA PRODUCTION

\begin{tabular}{ccc}
\multicolumn{3}{c}{ GROWTH PERIOD FOR BANANA PRODUCTION } \\
\hline Growth period & $\begin{array}{l}\text { Crop Coefficient }(\text { Kc) } \\
\text { of banana plantation }\end{array}$ & Months \\
\hline period 1 & 0.50 & Jan-Mar \\
period 2 & 0 & Apr-Sep \\
period 3 & 1.10 & Oct-Nov \\
period 4 & 1.00 & Dec \\
\hline \hline
\end{tabular}

Source: CROPWAT 8.0

2) Reference Crop Evapotranspiration (ET0)

The Reference Crop Evapotranspiration in this research was assessed by the Penman Monteith method. The 
Reference Crop Evapotranspiration per months was shown in Table VIII.

TABLE VIII: THE REFERENCE CROP EVAPOTRANSPRIRATION OF BANANA PLANTATION

\begin{tabular}{cccc}
\hline \hline Months & $\begin{array}{c}\text { Crop Coefficient } \\
\left(\mathbf{K}_{\mathbf{c}}\right)\end{array}$ & $\begin{array}{c}\mathbf{E T}_{\mathbf{0}} \\
(\mathbf{M M} / \mathbf{d a y s})\end{array}$ & $\begin{array}{c}\mathbf{E T}_{\mathbf{0}} \\
\text { (MM months) }\end{array}$ \\
\hline Jan & 0.50 & 109.43 & 54.71 \\
Feb & 0.50 & 112 & 56 \\
Mar & 0.50 & 141.36 & 70.68 \\
Apr & 0 & 144.6 & 0 \\
May & 0 & 150.35 & 0 \\
Jun & 0 & 121.5 & 0 \\
Jul & 0 & 112.22 & 0 \\
Aug & 0 & 106.95 & 0 \\
Sep & 0 & 108 & 0 \\
Oct & 1.10 & 114.08 & 125.48 \\
Nov & 1.10 & 112.5 & 123.75 \\
Dec & 1.00 & 108.81 & 108.81 \\
\hline Crop Water Requirement (CWR) $\mathbf{- 1 1 . 4}$ &
\end{tabular}

Crop Water Requirement $($ CWR $)=11.4$

Source: CROPWAT 8.0

3) Effective Rainfall and Weighted Rainfall

The effective rainfall and weighted rainfall were assessed by the difference value between crop water requirement and effective rainfall. The detail of factor use for calculation was shown in Table VIIII.

TABLE VIIII: THE FACTOR OF RAINFALL ASSESSMENT

\begin{tabular}{cc}
\hline Weighted Rainfall WRFL(MM) & Effective Rainfall Peff (MM) \\
\hline $0-10$ & 0 \\
$11-100$ & WRFL $\times 0.80$ \\
$101-200$ & WRFL $\times 0.70$ \\
$201-250$ & WRFL $\times 0.60$ \\
$251-300$ & WRFL $\times 0.55$ \\
$301-u p$ & WRFL $\times 0.50$ \\
\hline \hline
\end{tabular}

From the average of rainfall value in this area, the effective rainfall was selected and then multiplied for calculating the rainfall. The result showed that the collection data area was the high value of rainfall per year as $1,048.00 \mathrm{~mm} /$ year. Over 72.31 percent of rainfall value was found in the September for initial growth period. The detail of rainfall value calculation for banana plantation was shown in Table. Form the result finding, the values of rainfall value as $\mathrm{CWU}_{\text {green }}$ and $\mathrm{CWU}_{\text {blue }}$ of Thai banana plantation were $757.25 \mathrm{~mm}$ and $80.78 \mathrm{~mm}$, respectively (Table X-XII). Moreover, the values of rainy value as $\mathrm{CWU}_{\text {green }}$ and $\mathrm{CWU}_{\text {blue }}$ were 863.06 $\mathrm{MM} /$ area and $775.53 \mathrm{MM} /$ area. Hence, total water consumption of banana plantation was $1638.59 \mathrm{MM} / \mathrm{area}$.

\section{Water Footprint of Thai Banana Production}

TABLE X: THE RAINFALl VALUE CALCULATION OF BANANA PRODUCTION

\begin{tabular}{cccc}
\hline \hline Months & $\begin{array}{c}\text { WRFL } \\
\text { (MM/months) }\end{array}$ & $\begin{array}{c}\text { Factor } \\
\text { value }\end{array}$ & $\begin{array}{c}\text { Pe } \\
\text { (MM/months) }\end{array}$ \\
\hline Jan & 7.80 & 0 & 0 \\
Feb & 12.90 & 0.80 & 10.32 \\
Mar & 58.90 & 0.80 & 47.12 \\
Apr & 51.90 & 0.80 & 41.52 \\
May & 92.10 & 0.80 & 73.68 \\
Jun & 124.60 & 0.70 & 87.22 \\
Jul & 134.60 & 0.70 & 94.22 \\
Aug & 170.00 & 0.70 & 119 \\
Sep & 190.00 & 0.70 & 133 \\
Oct & 127.90 & 0.70 & 89.53 \\
Nov & 62.90 & 0.80 & 50.32 \\
Dec & 14.90 & 0.80 & 11.92 \\
\hline Total & $\mathbf{1 0 4 8 . 0 0}$ & - & $\mathbf{7 5 7 . 8 5}$ \\
\hline
\end{tabular}

From the field of observation form the 400 rai of banana farms with the 1.946 ton/rai of banana productivity, the water footprint was assessed by three categorized above.

TABLE XI: THE RAINFALl VALUE OF THAI BANANA PRODUCTION

\begin{tabular}{ccclc}
\hline Months & Pe & CWR & $\begin{array}{c}\text { Rainy } \\
\text { consumption }\end{array}$ & $\begin{array}{c}\text { Irrigation } \\
\text { water } \\
\text { consumption }\end{array}$ \\
\hline Jan & 0 & 54.71 & 1)CWR $=0$ & 0 \\
Feb & 10.32 & 56 & $1) \mathrm{CWR}=10.32$ & 56 \\
Mar & 47.12 & 70.68 & $1) \mathrm{CWR}=47.12$ & 70.68 \\
Apr & 41.52 & 0 & $2) \mathrm{Pe}=0$ & 0 \\
May & 73.68 & 0 & $2) \mathrm{Pe}=0$ & 0 \\
Jun & 87.22 & 0 & $2) \mathrm{Pe}=0$ & 0 \\
Jul & 94.22 & 0 & $2) \mathrm{Pe}=0$ & 0 \\
Aug & 119 & 0 & $2) \mathrm{Pe}=0$ & 0 \\
Sep & 133 & 0 & $2) \mathrm{Pe}=0$ & 0 \\
Oct & 89.53 & 125.48 & $1) \mathrm{CWR}=89.53$ & 125.48 \\
Nov & 50.32 & 123.75 & $1) \mathrm{CWR}=50.32$ & 123.75 \\
Dec & 11.92 & 108.81 & $1) \mathrm{CWR}=11.92$ & 108.81 \\
\hline Total & $\mathbf{7 5 7 . 8 5}$ & $\mathbf{5 3 9 . 7 3}$ & $\mathbf{7 5 1 . 2 5}$ & $\mathbf{4 8 4 . 7 2}$ \\
\hline
\end{tabular}

TABLE XII: THE RAINY VALUE OF THAI BANANA PRODUCTION

\begin{tabular}{ccccc}
\hline \hline Months & $\begin{array}{c}\text { Rainy } \\
\text { consumption }\end{array}$ & $\begin{array}{c}\text { Irrigation } \\
\text { water } \\
\text { consumption }\end{array}$ & $\begin{array}{c}\text { Rainy } \\
\text { consumption } \\
\text { for banana use }\end{array}$ & $\begin{array}{c}\text { Irrigation } \\
\text { water } \\
\text { consumption }\end{array}$ \\
\hline Jan & 54.71 & 0 & 87.53 & 0 \\
Feb & 56 & 56 & 89.6 & 89.6 \\
Mar & 70.68 & 70.68 & 113.08 & 113 \\
Apr & 0 & 0 & 0 & 0 \\
May & 0 & 0 & 0 & 0 \\
Jun & 0 & 0 & 0 & 0 \\
Jul & 0 & 0 & 0 & 0 \\
Aug & 0 & 0 & 0 & 0 \\
Sep & 0 & 0 & 0 & 0 \\
Oct & 125.48 & 125.48 & 200.76 & 800.76 \\
Nov & 123.75 & 123.75 & 198 & 198 \\
Dec & 108.81 & 108.81 & 174.09 & 174.09 \\
\hline Total & $\mathbf{5 3 9 . 7 3}$ & $\mathbf{4 8 4 . 7 2}$ & $\mathbf{8 6 3 . 0 6}$ & $\mathbf{7 7 5 . 5 3}$ \\
\hline
\end{tabular}

1) Green Water Footprint was the water volume in the pattern of humidity in soil. The green water footprint of banana plantation was assessed by the ratio of crop water use and plantation area. The assessment of green water footprint for banana production was following:

$$
\begin{aligned}
\text { WFgreen } & =\frac{863.06}{1.946} \\
& =443.50 \mathrm{~m}^{3 /} \text { ton }
\end{aligned}
$$

2) Blue Water Footprint was the natural water from the production and service use. The blue water footprint of banana production was assessed by the ratio of natural volume for banana production and banana volume for plantation area. The assessment of blue water footprint for banana production was following:

$$
\begin{aligned}
\text { WFblue } & =\frac{775.53}{1.946} \\
& =398.52 \mathrm{~m}^{3} / \mathrm{ton}
\end{aligned}
$$

3) Grey Water Footprint was the water volume use in the process of wastewater treatment from the production and service process. Form the observation in the banana farm found that the chemical and fertilizer in the process of banana plantation was not contamination in the environment. Hence, the grey water footprint was not the 
scope of this study.

4) Water footprint of product was the water use volume of production in the life cycle for the product and service. Water footprint of production was assessed by the total water use of the whole process of the 1 ton of banana product. The assessment of water footprint for banana production was following:

$$
\begin{aligned}
\text { WFTotal } & =\text { WFgreen }+ \text { WFblue }+ \text { WFgrey } \\
& =443.50+398.52+0 \\
& =842.02 \mathrm{~m}^{3} / \text { ton }
\end{aligned}
$$

Form the result finding, the water use volume of 1 ton of banana production in this study was $842.02 \mathrm{~m}^{3}$, which consisted of $443.50 \mathrm{~m}^{3} /$ ton of rain water use $(53 \%$ of total water use) and of $398.52 \mathrm{~m} 3 /$ ton of natural water use (47\%f total water use). Hence, water use volume of 1 rai of banana plantation area was $863.06 \mathrm{~m}^{3} / \mathrm{rai}$, (53\% of total water use) and $775.53 \mathrm{~m}^{3} /$ ton of natural water use (47\%f total water use)

The comparison of water footprint value for banana plantation with other countries was shown in Table XIII. The result found that the water footprint value of Thai banana production was lower than Indonesian banana because the climatic pattern of Indonesia was shown in the high water volume in the rainy season and Iceland area. However, the water footprint of Peru banana was lower than Thai banana the climatic pattern of Peru was presented in the high humanity and high water volume in the rainy season.

TABLE XIII: THE COMPARISON OF WATER FOOTPRINT VALUE FOR BANANA PLANTATION WITH OTHER COUNTRIES

\begin{tabular}{cc}
\hline Area & $\begin{array}{c}\text { Water Footprint } \\
\left(\mathbf{m}^{\mathbf{3}}\right)\end{array}$ \\
\hline Thai banana (This study) & 842.02 \\
Indonesian banana & 875 \\
Peru banana & 576 \\
\hline \hline
\end{tabular}

Source: L. Clercx [13]

\section{E. Management Approach of Water Use Reduction for Banana Production}

From the finding of water footprint assessment for Thai banana product, the main source of water use for banana plantation was watering process. Then, the reduction of watering process in each growth period of banana plantation should be proposed and concerned. In the industry process, the cleaning process of raw material as banana should be considered and reused for other process in the industry.

\section{CONCLUSION AND RECOMMENDATION}

This study was to present the results of the water footprint assessment for Thai banana production. The production chains of Thai banana production process consisted of banana plantation and banana production in the industry, which was assessed based on 1 ton of banana production. The results showed that the water footprint of banana plantation was $842.02 \mathrm{~m}^{3}$ including $443.50 \mathrm{~m}^{3}$ of green water, 398.52 $\mathrm{m} 3$ of blue water and not found grey water. Moreover,
$1638.59 \mathrm{~m}^{3} /$ rai was found in the one rai of banana plantation consisted of $863.06 \mathrm{~m}^{3} /$ rai of green water and $775.53 \mathrm{~m}^{3} /$ rai of blue water. From this finding, the main source of water use for banana plantation was watering process. Hence, the reduction of watering process in each growth period of banana plantation and the water reused from the clearing process to other process in the industry should be recommendation of water footprint reduction.

\section{CONFLICT OF INTEREST}

The authors declare no conflict of interest.

\section{AUTHOR CONTRIBUTIONS}

Conceptualization, and methodology, C.R. ; data collection and data analysis, W.O.; and writing, W.O.

\section{REFERENCES}

[1] P. Powthong, B. Jantrapanukorn, P. Suntornthiticharoe and K Laohaphatanalert, "Study of prebiotic properties of selected banana species in Thailand," Journal of Food Science and Technology, vol. 57 , no. 7, pp. 2490-2500, 2020.

[2] B. S. Padam, H. S. Tin, F. Y. Chye, and M. I. Abdullah, "Banana byproducts: An under utilized renewable food biomass with great potential," Journal of Food Science and Technology, vol. 51, pp. 3527-3545, 2014.

[3] R. C. S. Mazareli, A. C. Villa-Montoya, T. P. Delforno, V. B. Centurion, V. M. Oliveira, E. L. Silva, and M. B. Am^^ancio Varesche, "Metagenomic analysis of autochthonous microbial biomass from banana waste: Screening design of factors that affect hydrogen production," Biomass and Bioenergy, vol. 138, p. 105573, 2020.

[4] C. Rattanapan and W. Ounsaneha, "Environmental impact assessment of Thai banana supply chain," International Journal of Environmental Science and Development, vol. 11, no. 7, July 2020.

[5] Office of Agricultural Economics. (2013). Agricultural Statistics of Thailand. [Online]. Available: http://oldweb.oae.go.th/download/ download_journal /commodity57.pdf

[6] T. Oki and S. Kanae, "Global hydrological cycles and world water resources," Science, vol. 313, pp. 1072-1068, 2006.

[7] A. Y. Hoekstra and M. M. Mekonnen, "The water footprint of humanity," in Proc. the National Academy of Sciences of the United States of America, vol. 109, pp. 3232-3237, 2012.

[8] C. J. Vörösmarty, A. Y. Hoekstra, S. E. Bunn, D. Conway, and J. Gupta, "What scale for water governance," Science, vol. 349, pp. 478-479, 2015.

[9] A. Muratoglu, "Water footprint assessment within a catchment: A case study for Upper Tigris River Basin,” Ecological Indicators, vol. 106, p. $105467,2019$.

[10] M. M. Mekonnen and A. Y. Hoekstra, "The green, blue and grey water footprint of crops and derived crop products," Hydrology and Earth System Sciences, vol. 15, pp. 1577-1600, 2011.

[11] A. E. Ercin and A. Y. Hoekstra, "Carbon and water footprints," Concepts, Methodol. Policy Responses, pp. 1-24, 2012.

[12] ISO, "Environmental management-water footprint-principles, requirements and guidelines. International Standards Organisation," Geneva, 2014.

[13] L. Clercx, E. Z. Torres, and J. D. Kuiper, "Water footprint assessment of bananas produced by small banana farmers in Peru and Ecuador," Acta Horticulturae, vol. 1112, pp. 1-7, 2016.

[14] S. Pongpinyopap, W. Saibuatrong, J. Mungkalasiria, R Wisansuwannakorn, T. Mungcharoen, and T. R. Srinophkun, "Water footprint assessment of palm oil biodiesel production in southern part of Thailand," Environment and Natural Resources Journal, vol. 12, pp. 42-46, 2014.

[15] E. Svanes and A. K. S. Aronsson, "Carbon footprint of a Cavendish banana supply chain," The International Journal of Life Cycle Assessment, vol. 18, pp. 1450-1464, 2013.

Copyright (C) 2021 by the authors. This is an open access article distributed under the Creative Commons Attribution License which permits unrestricted use, distribution, and reproduction in any medium, provided the original work is properly cited (CC BY 4.0). 


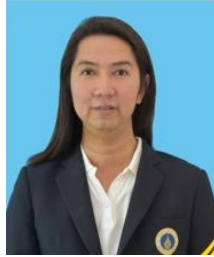

Cheerawit Rattanapan was appointed to an associate professor of ASEAN Institute for Health Development, Mahidol University, Thailand in October, 2018 with the qualification on the post doctoral research in sustainable development at Vienna University of Economics and Business, Austria. Over 10 years of experience research in environmental management and technology were conducted.

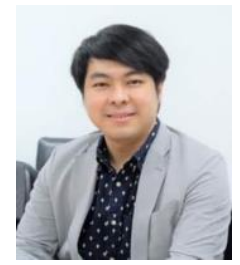

Weerawat Ounsaneha was appointed to an Assistant Professor in environmental technology at environmental science program, Faculty of Science and Technology, Valaya Alongkorn Rajabhat University under the Royal Patronage, Thailand. He received the Ph.D. in environmental management from Prince of Songkla University, Thailand. 